\title{
Identification and characterization of pill, a highly conserved pilus-assembly gene in pathogenic Neisseria
}

Tone Tønjum, ${ }^{1 *}$ Nancy E. Freitag, ${ }^{2}$ Ellen Namork $^{3}$ and Michael Koomey ${ }^{2}$

${ }^{1}$ Kaptein W. Wilhelmsen og Frues Bakteriologiske

Institutt, Rikshospitalet (National Hospital), University of

Oslo, N-0027 Oslo 1, Norway.

${ }^{2}$ Department of Microbiology and Immunology, University

of Michigan Medical School, Ann Arbor, Michigan

48109-0620, USA.

${ }^{3}$ Electron Microscopy Unit, National Institute of Public

Health, 0462 Oslo, Norway.

\section{Summary}

Expression of type IV pili appears to be a requisite determinant of infectivity for the strict human pathogens Neisseria gonorrhoeae and Neisseria meningitidis. The assembly of these colonization factors is a complex process. This report describes a new pilusassembly gene, pilG, that immediately precedes the gonococcal (Gc) pilD gene encoding the pre-pilin leader peptidase. The nucleotide sequence of this region revealed a single complete open reading frame whose derived polypeptide displayed significant identities to the pilus-assembly protein PilC of Pseudomonas aeruginosa and other polytopic integral cytoplasmic membrane constituents involved in protein export and competence. A unique polypeptide of $M_{\mathrm{r}} 38 \mathrm{kDa}$ corresponding to the gene product was identified. A highly related gene and flanking sequences were cloned from a group $\mathrm{B}$ polysaccharide-producing strain of $N$. meningitidis $(\mathrm{Mc})$. The results indicate that the pilG genes and genetic organization at these loci in $\mathrm{Gc}$ and Mc are extremely conserved. Hybridization studies strongly suggest that pilG-related genes exist in commensal Neisseria species and other species known to express type IV pili. Defined genetic lesions were created by using insertional and transposon mutagenesis and moved into the $\mathrm{Gc}$ and Mc chromosomes by allelic replacement. Chromosomal pilG insertion mutants were devoid of pili and displayed

Received 25 October, 1994; revised 11 January, 1995; accepted 13 January, 1995. "Present address for correspondence: Department of Microbiology. Ullevall Hospital, University of Oslo, N-0407 Oslo, Noway. Tel. 221188 25; Fax 22741596. dramatically reduced competence for transformation. These findings could not be ascribed to pilin-gene alterations or to polarity exerted on pilD expression. The results indicated that PilG exerts its own independent role in neisserial pilus biogenesis.

\section{Introduction}

Infections caused by Neisseria gonorrhoeae (Gc) and Neisseria meningitidis (Mc), pathogenic members of the genus Neisseria, are associated with significant morbidity and mortality for their exclusively human hosts. Despite the unique disease manifestations associated with these species, it appears that their basic strategies for successful colonization of man are highly conserved. Many studies have focused on understanding the structures and functions of surface-localized and extracellular neisserial components. The expression of pili, which are filamentous-like structures emanating from the bacterial surface, appears to be of paramount importance to the pathogenic process (Heckels, 1989). Gc and Mc pilus filaments are ordered arrays of polymerized protein subunits termed pilin. The short leader sequences and proximal 30 amino acids of their pre-pilins (Meyer et al., 1984; Potts et al., 1988) show a high dégree of homology with pre-pilins of other Gram-negative human pathogens including Pseudomonas aeruginosa (Pasloske et al., 1985), Vibrio cholerae (Shaw and Taylor, 1990) and certain strains of enteropathogenic Escherichia coli (Giron et al., 1991). Collectively, members of this family of pilus colonization factors have been termed type IV pili. Evidence for critical roles of $\mathrm{Gc}$ and $\mathrm{Mc}$ pili can be found in the invariable recoveries of piliated organisms from primary cultures (Jyssum and Lie, 1965; Kellogg et al., 1968; Swanson et al., 1987) and the capacities of these structures to undergo antigenic variation (Tinsley and Heckels, 1986; Swanson et al., 1987). Gc pilus variation results from homologous recombination between a single complete pilin gene or expression locus and multiple partial pilin gene copies or silent alleles (Haas and Meyer, 1986; Swanson et al., 1986; Koomey et al., 1987) and an analogous mechanism is thought to operate in Mc pilus variation (Aho and Cannon, 1988; Perry et al., 1988; Blake et al., 1989).

Neisserial pili appear to promote infectivity by mediating attachment to mucosal epithelia (Swanson, 1973; Stephens 
and McGee, 1981) although their presence is also associated with other phenotypes which may be relevant to the host-parasite interaction. Pilus expression is correlated with high-level (sequence-specific) competence for DNA transformation with frequencies of recovered transformants being reduced 1000 -fold in non-piliated mutants (Froholm et al., 1973; Seifert et al., 1991; Zhang et al., 1992). Bacterial autoagglutination (independent of that associated with Opa proteins) is a pilus-dependent phenomenon (Swanson et al., 1971) and a form of bacterial surface translocation termed 'twitching motility' is only displayed by piliated organisms (Swanson, 1978). The basis for the associations between these phenotypes and piliation is not well understood.

Studies directed at understanding neisserial pilus biogenesis appear to be particularly well suited to addressing basic questions about organelle structure, function and related phenotypes. Until recently, relatively little was known about this aspect of Gc and Mc pili. Studies of spontaneously arising Gc pilin mutants, as well as those created by site-specific mutagenesis and allelic replacement, have led to the identification of specific amino acid residues and domains of pilin which are required for pilus biogenesis (Koomey et al., 1991; Zhang et al., 1992). A $110 \mathrm{kDa}$ protein, PilC, that co-purifies with the Gc pilin subunit and its corresponding gene has been identified (Jonsson et al., 1991). Gc mutants failing to express PilC were reported to have a significant reduction in piliation (Jonsson et al., 1991) and analogous observations have been made in Mc (Nassif et al., 1994).

The assembly of pili invariably involves the interaction of pilin and other accessory proteins which act to modify, transport and polymerize pilin into the extracellular structures (Hultgren and Normark, 1991). In the type IV pilus systems of $P$. aeruginosa and $V$. cholerae, the genes encoding these ancillary components are linked to the gene encoding the pilus subunit (Nunn et al., 1990; Kaufmann et al., 1993) but this gene clustering does not exist in Gc and Mc. Evidence derived from many prokaryotic systems has revealed that components required for the translocation of proteins to the cell surface are structurally and functionally related to proteins necessary for type IV pilus biogenesis (Whitchurch et al., 1991; Pugsley 1993; Hobbs and Mattick, 1993). At least three distinct families of genes and corresponding proteins which share significant sequence identity across diverse species boundaries have been proposed to be part of the conserved apparatus of extracellular protein localization. Proteins corresponding to one or more of these families have been implicated in the extracellular localization of toxins and hydrolases by many pathogenic Gram-negative bacteria including $V$. cholerae (Sandkvist et al., 1993), Bordetella pertussis (Weiss et al., 1993), Aeromonas hydrophila (Jiang and Howard, 1992), and P. aeruginosa (Bally et al., 1991b;
Strom et al., 1991). Related proteins are also involved in competence for DNA transformation in Bacillus subtilis (Albano et al., 1989).

We have previously identified the Gc pilFand pilD genes which encode products displaying significant identities with the NTP-binding domain containing homologues and the family of pre-pilin leader peptidases (Lauer et al., 1993). The Gc gene products are most closely related to the type IV pilus-assembly proteins PilB and PilD of $P$. aeruginosa, respectively (Nunn et al., 1990; Bally et al., 1991a). In this report, we describe the identification of the $\mathrm{Gc}$ and Mc pilG genes which map immediately upstream of their pre-pilin peptidase-encoding pilD genes. Their products are highly related to the pilusassembly protein PilC of $P$. aeruginosa and other polytopic integral cytoplasmic membrane constituents involved in the formation of surface-localized protein complexes. $\mathrm{Gc}$ and Mc pilG mutants were constructed by allelic replacement and found to be absolutely deficient in the assembly of pili. In addition, DNA hybridization studies strongly suggest that pilG-like genes are present in related bacterial species.

\section{Results}

\section{Cloning and characterization of the DNA region upstream of pilD in N. gonorrhoeae}

The Gc pilD gene encodes a pre-pilin leader peptidase which has been demonstrated to be essential for pilus biogenesis (Freitag et al., 1995). In order to detect other genes potentially involved in pilus biogenesis, the region of plasmid clones (Fig. 1) containing sequences upstream of pilD was further analysed by subcloning and DNA sequencing. An open reading frame (ORF) was identified upstream of, and in the same orientation as, pilD (Fig. 2). The DNA sequence of this locus appears in the EMBL/Genbank/DDBJ Nucleotide Sequence Data Libraries under the accession number U19579 (data not shown). This ORF had an in-frame ATG start codon at nucleotide position 219. Its derived polypeptide beginning at that site would consist of 393 amino acids, having a molecular mass of $45.3 \mathrm{kDa}$ and a pl of 9.4. The deduced polypeptide did not appear to possess a typical secretion signal sequence but was mainly hydrophobic in character with four potential membrane-spanning helices (Rao and Argos, 1986). Sequences immediately downstream of the predicted translation termination site demonstrated a strong potential to form a stable stem and loop RNA structure ( $\triangle \mathrm{G}$ $\left(25^{\circ} \mathrm{C}\right)=-21.3 \mathrm{kcal} \mathrm{mol}^{-1}$ using the Fold program of the GCG software package). Its presence in RNA might act as a signal for transcription termination/attenuation or nucleolytic processing (Jaeger et al., 1989). The intergenic region between this ORF and the pilD ORF encompassed 

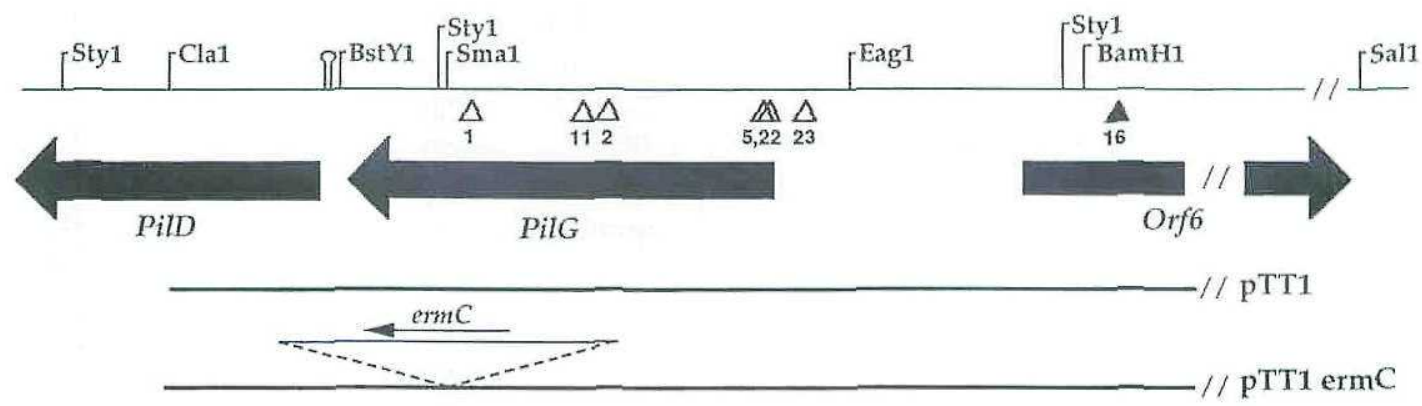

pTT2

$/ /$ PTT3

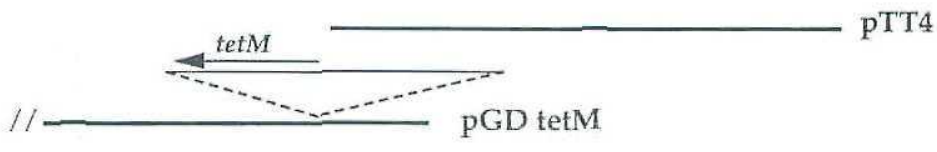

pTT5

$0.5 \mathrm{~kb}$

Fig. 1. Physical map of the pilG locus in pathogenic Neisseria and plasmid constructs derived from these regions. The nucleotide sequences of the pilG genes of N. gonorthoeae N400 and N. meningitidis 44/76-A appear in the EMBL/GenBank/DDBJ Nucleotide Sequence Data Libraries under the accession numbers U19579 and U19580, respectively. Seven mTnErm insertions generated in the plasmid pTT3 in E. coli and recombined into the Gc and Mc genomes are shown. Precise sites of pilG::mTnErm insertions within this nucleotide sequence are GG23, position 88; GG5, position 215; GG22, position 219; GG2, position 697; GG11, position 787; and GG1, position 1099. Symbols: open triangles, locations of insertions resulting in loss of piliation; filled triangle, site of insertion which does not alter pilus phenotype. Details of plasmid constructs are described in Table 4 and in the text. Note that the inserts containing the erm $C$ and tetm genes are not drawn to scale. The region of dyad symmetry downstream of pilG is depicted by a stem and loop structure.

73 nucleotides. Based on its linkage with pilD, the findings cited below and the nomenclature established in our other studies, we have designated the corresponding gene pilG.

The derived polypeptide of the pilG ORF is a homologue of components required for type IV pilus assembly and protein export

In a computer-assisted database search, the deduced PilG polypeptide exhibited significant sequence similarity to these proteins in the following order of decreasing identity: $P$. aeruginosa PilC (Nunn et al., 1990), P. aeruginosa XcpS (Bally et al., 1991b), Xanthomonas campestris XpsF (Dums et al., 1991), Erwinia chrysanthemi OutF ( $\mathrm{He}$ et al., 1991), A. hydrophila ExeF (Jiang and Howard, 1992), and Klebsiella oxytoca PulF (Pugsley and Reyss, 1990) (Table 1). It also displayed regions of similarity to $B$. subtilis Com-G2 (Albano et al., 1989) and V. cholerae TcpE (Kaufmann et al., 1993), but to a lesser extent than the others cited above. The regions of similarity shared by these proteins were equally distributed over their entire lengths (Fig. 3). These proteins are components involved in pilus assembly or export of other proteins (Hobbs and Mattick, 1993; Pugsley, 1993). All members of the protein family display an overall hydrophobic character and are predicted to be located in the cytoplasmic membrane (Nunn et al., 1990; Bally et al., 1991b).

\section{Identification of an expressed polypeptide corresponding to Gc PilG}

We next sought to identify a polypeptide expressed by

N. gonorrhoeae, N. meningitidis

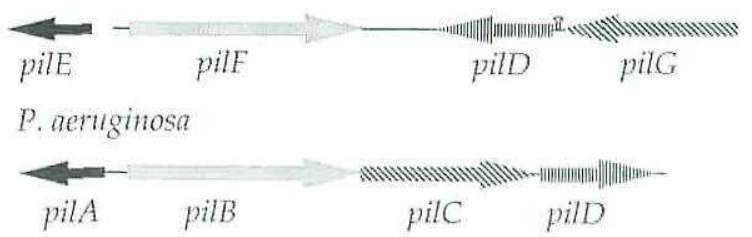

Fig. 2. Relative genetic organization of the pilG assembly gene clusters of $N$. gonorrhoeae $N 400$ and $N$. meningitidis 44/76-A, in comparison with the pilus-assembly gene cluster of $P$. aeruginosa. Note that pilE, the pilin subunit-encoding gene of Gc and Mc, is not linked to this region as it is in $P$. aeruginosa. 
Table 1. Overall sequence similarity between Gc PilG and other members of the PilC/PulF family of proteins.

\begin{tabular}{lll}
\hline Homologue & \% identity & $\%$ similarity \\
\hline PilC & 45.6 & 69.2 \\
XcpS & 31.2 & 56.9 \\
XpsF & 30.6 & 56.7 \\
OutF & 30.3 & 57.3 \\
ExeF & 28.7 & 58.7 \\
PulF & 28.6 & 56.4 \\
\hline
\end{tabular}

Scores were obtained using the BESTFIT program of the GCG sequence analysis package from the University of Wisconsin.

cloned DNAs that corresponded to PilG. This was done using in vitro transcription-translation analysis of plasmid DNAs. By comparison with the pattern found using the cloning vector pACYC184, $\mathrm{p} T 11$ (Fig. 1) primed reactions yielded major unique polypeptides with molecular masses of $55 \mathrm{kDa}$ and $38 \mathrm{kDa}$ (Fig. 4, lanes 1 and 2). Further comparison with the pattern found using $p \pi 1_{\text {is Xmal }}$ which carries a specific frameshift mutation in pilG confirmed that the $38 \mathrm{kDa}$ species corresponded to PilG (Fig. 4, lane 3). In addition, the unique polypeptide of molecular mass $24 \mathrm{kDa}$ detected for $\mathrm{p} T 2_{\text {is }}$ mal correlated well with the size predicted for truncated PilG resulting from premature translational termination. Analogous results were found using $\mathrm{PTT} 4$ DNA and other plasmids as templates (data not shown). It should be noted that the P. aeruginosa PilC protein, which is most closely related to PilG, has a predicted molecular mass of $44.5 \mathrm{kDa}$ but migrates with an apparent molecular mass of $37 \mathrm{kDa}$ (Nunn et al., 1990).

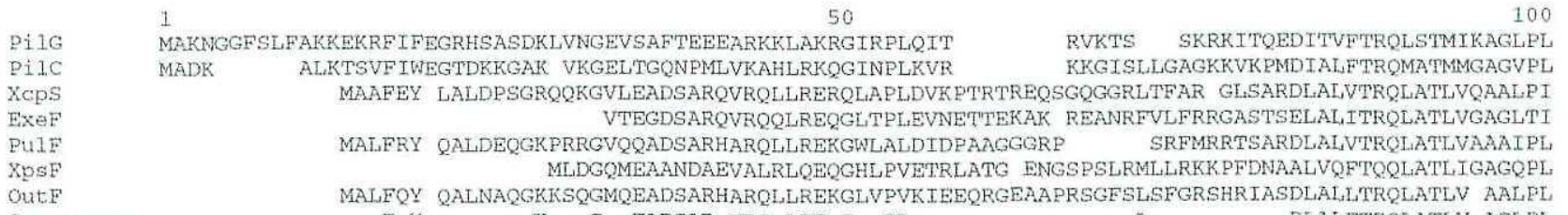

Consensus $\quad$ MLFQY OALNAQGKTSQGMOEADSARHAROLLREKGLVPVKTEEORGEAAPRSGESLSFGRSHRIASDLALLTRQLATLV AALPI

$101 \quad 200$

PiIG MQAFEIVARGHGNPSMTEMLMEIRGQVEQGSSLSRAFSNHPKYFDRFXCNLVAAGETGGVLESLLDKLAIYKEKTQAIRKKVKTALTYPVSVIAVAIGLV PiIC LOSFDIIGEGFDNPNMRKLVDETKOEVSSGNSLANSLRKKPOYFDELYCNLVDAGEQSGALENLLDRVATYKEKTESLKAKIKKAMTYPIAVIIVALIVS XCPS EEALRAAAAQSTSQRIQSMLLAVRAKVLEGHSLAGSLREFPTAFPELYRATVAAGEHAGHLGPVLEQLADYTECRCQSRQKTQLALLYPVILMVASLAIV Exer

PulF

XpsF

cutF

Consensus EEALRAVAEQCEKAHLRSIVATVRSKVVEGY SLADSLGAFPHVFDQLFRSMVAAGEKSGHLEKVLNRLADXTEQRQHMRTKLLQAMIY PTVLTLVAVGV EKALDAVAOOSEKPOLKTL IAGVRGKVLEGHSLAEAMRGHPGCFDALYCAMVAAGEASGH RLLOAMIYPIVLTLVAVSVI DRALS ILMDLPEDDKSRRVIADIRDTV. RAAPLSVALERQHGLFSKLY INMVRAGEAGGSMQDTLQRLADYLERSRALKGKVINALIYPAILIAVVGCAI EEALDAVAKQSEKPKLSALMAAVRAKVVEGHSLAEAMGNF FGSFERLYCAMVAAGEASGHLDAVLNRLADY'TEQRHEMRSRIQQAMIY PCVLTLVAISVV E ALDAVA Q E P L I A VR KV EG SLA AL P FD LYC MVAAGE SGHLE L RLADY E R KI AMIXPIVI, VA VY FVMMI FVL PAFKEVYAMMGAFL PPLTOTVMDMSDFRVSYGWMVL IALGFA TYGFI KLKARSIK IORFMDA ILLRMPIFGDTVRKGTIARWGRTTATLFAA AILLIKVVPQFQSVFEGFGAELPAFTQMIVNLSEFMQEWWFFIILAIAIFGFAFKELHKRSQRFRDTLDRTILKLPIFGGIVYKSAVARYARTLSTTFAA GFLLGVVVPDVVRVFIDSGQTLPLLTRVLIGVSDWVKAWGALAFVAAIGGVIGF RYALRKDAFRERWHGFLLRVPLVGRLVRSTDTARFASTLAILTRS STLLTAVVPKVVAOF'EHMGOOLPATTRFI_IGTSELMOHYGLWFL,LLFIGGFVW RWWLTDEKRRRHWHOVVLRLPVIGRVSRGLNTARFARTLSILNAS VILLSTVVPKVVEQF THLIKOALPFSTRLIMAMSDMLRAAGPWLLLATLLLILLL RYLLRQPAKRLAWHRLLLRLPLIGRVARSVNSARYARTLSTLNAS LFLLGYVVPOFAOMYESLDVALFWFTQAVLSVGLLVRDWWLVLVVIPGVLGL WLDRKRRNA.AFRAALDAWLLRQKVIGSLIARLETARLITRTLGTLLRN SILLSAVVPKVVEQF IHMROALPLSTRLLMSASDAVRTYGEWVVLLLVLAIMGF RVLLRQEKHRL,VFHRRLLFLPVVGRVARGLNTARYARTLSILNSS Consensus TLL VVP VV F MGQ LPL TRLLM SD M GLW LLA I E RY LR K R WH LLRLPVIGRVVR TARYARTLSIL AS

\begin{tabular}{|c|c|}
\hline & 301 \\
\hline PilG & GVPLVDVLDSTAGAAGNLIYEEAT \\
\hline PilC & GVPLVDALDSVSGATGNIVFKNAV \\
\hline $\mathrm{Xcps}$ & GVPLVEALAIAAEVIANRI IRNEV \\
\hline ExeF & AVPLLEGMKIAGEVLSNDFPRTRI \\
\hline Pulp & AVPLILAMRISADVLSNAWAKRQL, \\
\hline XpsF & GVPLLAAIGIARIVVMSNTALVEDV \\
\hline Out F & AVPLLQANR I SGDVLTNDYAPFRL \\
\hline \multirow[t]{2}{*}{ Consensus } & GVPLL A I VL $N$ V \\
\hline & 401 \\
\hline PiLG & VIGTLLVAMYLPLFNLGNVVA* \\
\hline Pilc & LVGGLIVAMYLPIFQLGNVVG* \\
\hline $\mathrm{xans}$ & VVLVIVLAILLPILSLNQLVG* \\
\hline ExeF & VVLFIVMSILQPILELNNMVNIL* \\
\hline PUIF & MVLFIVLAILQPILQLNTLMSM* \\
\hline XpsF & VVGLVIISVLVPLYDLTENAIG* \\
\hline outF & IVLFIVLAILQPILQLNTLMSM* \\
\hline Consensug & VVLFIVIAIL PIL LNMLU \\
\hline
\end{tabular}

Fig. 3. Comparative alignment of the deduced amino acid sequences of PilG and homologues was performed by using the GAP Program of the UWGCG package. A consensus sequence based on sites in which a majority of sequences display identical residues is shown beneath Underlined residues represent those regions with a strong potential to form membrane-spanning helices according to a specified algorithm (Rao and Argos, 1986). The precise sequence identities and similarities are shown in Table 2. 
$\begin{array}{lll}1 & 2 & 3\end{array}$

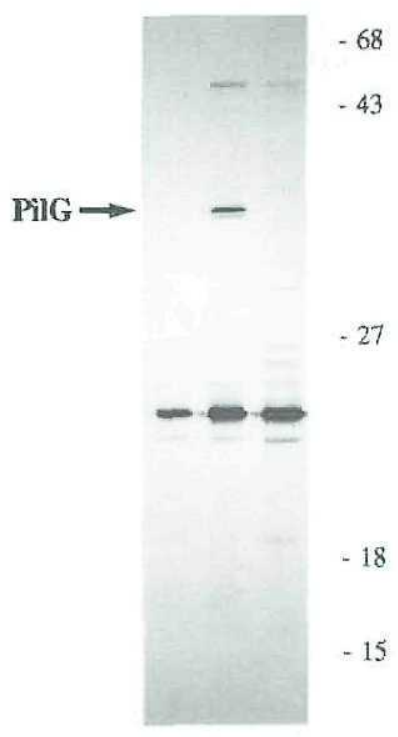

Fig. 4. In vitro coupled transcription/translation analysis of $\mathrm{PACYC}$ 184 (lane 1), p Tा (lane 2) and $\mathrm{p} T 1_{\text {is } x_{\text {mal }}}$ (lane 3 ) as analysed by SDS-PAGE. The relative mobilities of protein molecular mass standards are shown in $\mathrm{kDa}$ on the left. Proteins were labelled by the incorporation of $\left[^{35} \mathrm{~S}\right]$-methionine using an $\mathrm{S} 30$ extract. The pilG gene product is indicated by an arrow.

\section{Characterization of the meningococcal pilG gene and linked gene organization}

Southern hybridization analysis using Gc pilG as a probe against $N$. meningitidis genomic DNA gave a strong signal under stringent conditions, suggesting a high homology between Gc pilG and its counterpart in N. meningitidis (data not shown). To further assess this possibility, the homologous locus from Mc strain 44/76-A was cloned from a genomic phage library and subcloned into plasmid vectors. The DNA sequence of this locus appears in the EMBL/Genbank/DDBJ Nucleotide Sequence Data Libraries under the accession number U19580. Thirteen nucleotide differences were found between $G_{c}$ and Mc sequences over this whole region and of these, only six result in PilG amino acid substitutions. Further characterization of the Mc locus in PTT5 (Fig. 1) by restriction mapping and partial DNA sequencing (data not shown) has revealed that the relative organization of the pilD, pilF and pilG genes is also highly conserved between Gc and Mc (Fig. 2).

\section{Characterization of gonococcal and meningococcal pilG transposon and insertion mutants}

To assess directly the potential role of pilG in pilus biogenesis, the plasmid p $\Pi 33$ was subjected to transposon mutagenesis. These insertions were then moved into the chromosome of Gc strain N400, a background in which
RecA expression and recombination functions are under the control of an inducible promoter. After ensuring the correct introduction of the mutations by Southern hybridization analysis (data not shown) and that no changes in pilE sequence (the pilin subunit gene) had been incurred during the process, pilus expression and associated phenotypes were assessed. Mutants carrying insertions in and immediately upstream of pilG displayed non-piliated colony morphotypes and were devoid of pili when examined by transmission electron microscopy (TEM) (Fig. 5). Identical results were found using a derivative which carried an insertion of an ermC gene cassette at the unique Smal site in pilG. These results were in direct contrast to mutants carrying insertions further upstream from pilG which were unperturbed in pilus expression and its associated pattern of growth. This class of mutants was exemplified by strain GG16, whose site of insertion maps within a large ORF (designated here as ORF6) that is oriented divergently from pilG. Expression of this ORF accounts for the $55 \mathrm{kDa}$ polypeptide seen in the in vitro transcriptiontranslation analysis and its derived polypeptide shows significant identity with the phosphoglucoseisomerase of $E$. coli (T. Tønjum, unpublished).

Immunoblotting of whole-cell lysates of the isogenic Gc strains was performed to assess the levels of pilin expression in these backgrounds. Although the amounts of pilin antigen detected were equivalent in all cases, the patterns of pilin species were specifically and identically altered in the pilG mutants (Fig. 6). In N400, pilin was detected as a doublet of approximately $18 \mathrm{kDa}$, and the faster migrating species seen here co-migrated with pilin present in pili purified by repeated cycles of solubilization and isoelectric precipitation (data not shown; Koomey et al., 1991). When compared with the pattern found using a mutant that expresses pilin incapable of being processed by Gc PilD (the pre-pilin leader peptidase), it is clear that both bands of the doublet seen in $\mathrm{N} 400$ appear to have been $\mathrm{N}$-terminally processed. In all the pilG mutants, however, only the slower migrating species of the doublet seen in $\mathrm{N} 400$ was found. Both doublet species present in N400 and the slower migrating species seen in pilG mutants reacted with $P$. aeruginosa PAK pilus-specific antiserum, which has been demonstrated to recognize only pilins processed by prepilin leader peptidase (Koomey et al., 1991; data not shown). In addition, pilin antigen migrating at a position characteristic of S-pilin (soluble, truncated pilin) was seen for each mutant (Fig. 6). Immunoblotting of concentrated culture supernatants confirmed that all the pilG mutants elaborated S-pilin. The presence of S-pilin has previously been correlated with defects in pilus assembly arising from pilin gene alterations (Haas et al., 1987; Koomey et al., 1991) and pilC mutations (Jonsson et al., 1992).

Many studies have shown that non-piliated Gc mutants 

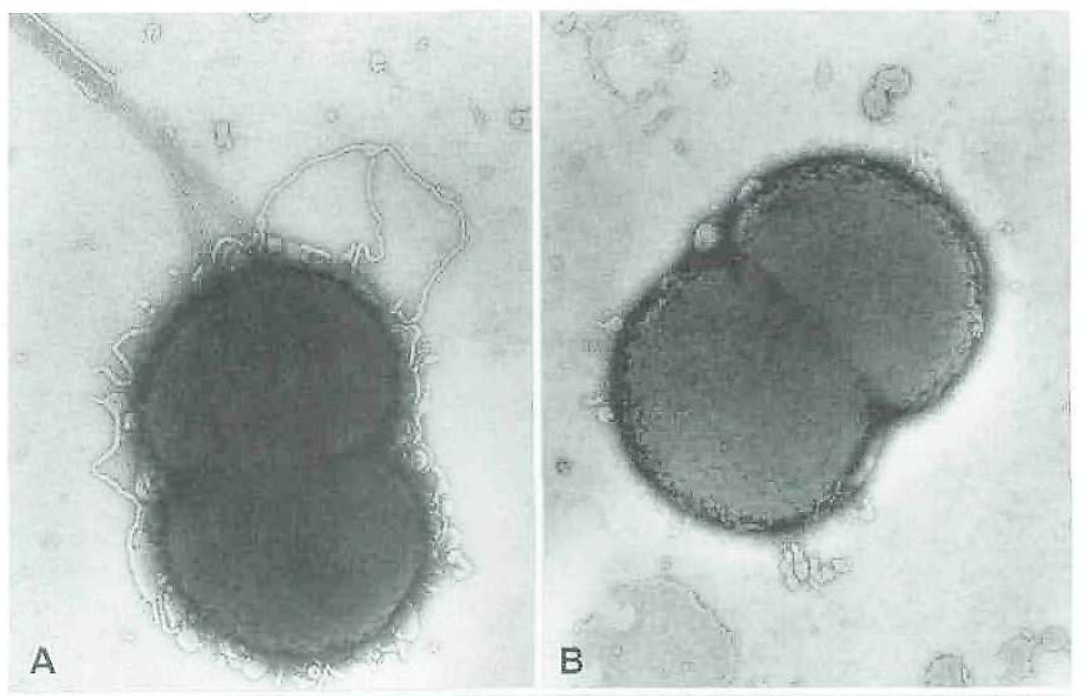

Fig. 5. Transmission electron micrographs of N. gonorrhoeae strains $N 400(A)$ and GG2 (B) and $N$. meningitidis strains $44 / 76-A(C)$ and MG1 (D). Other mutant pilG derivatives gave results identical to that seen with GG2. The specimens were negatively stained with $0.25 \%(\mathrm{Gc})$ and $0.5 \%(\mathrm{Mc})$ phosphotungstic acid. Magnification 29250x.
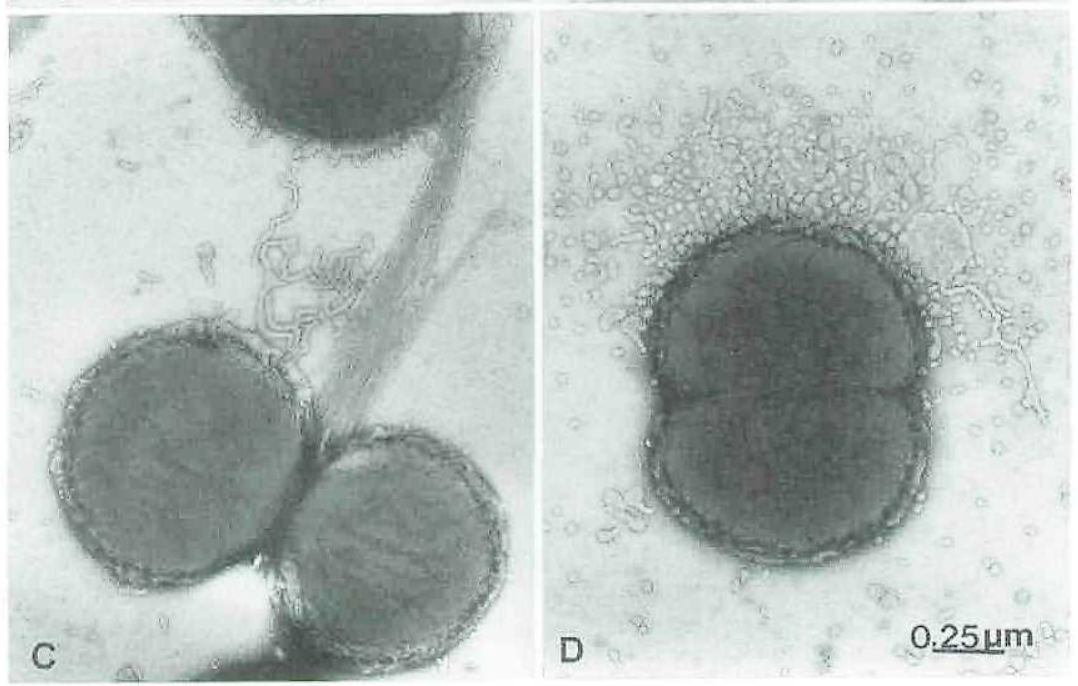

are dramatically reduced in competence for natural transformation and, thus, pilus expression appears to be necessary for this property. However, antigenic variants that express extremely low levels of pili are transformable at frequencies equivalent to that seen for extensively piliated strains (Gibbs et al., 1989). Given that competence for transformation is an extremely sensitive marker for pilus expression, we examined the relative competence of $\mathrm{N} 4.00$ and its isogenic derivatives. All mutants shown to lack pili by TEM had over a 1000-fold reduction in their transformation competence (Table 2). These levels of competence are equivalent to that found for non-piliated mutants resulting from pilE lesions (Seifert et al., 1991; Zhang et al., 1992).

The same transposon and insertion mutants were moved onto the chromosome of Mc strain 44/76-A. As anticipated from the results in Gc, the Mc pilG mutants were non-piliated (Fig. 6) and expressed dramatically reduced competence for transformation (data not shown).
Although the pilin gene status was not specifically examined in this background (because this strain is wild type with regard to homologous recombination functions), it is important to note that all primary transformants were

Table 2. Phenotypic characteristics of Neisseria gonorrhoeae $\mathrm{N} 400$ and pilG::mTnErm mutants.

\begin{tabular}{lcccl}
\hline Strain & Pili & Aggregation & $\begin{array}{l}\text { S-pilin } \\
\text { expression }\end{array}$ & $\begin{array}{l}\text { Transformation } \\
\text { frequencies }\end{array}$ \\
\hline N400 & + & + & - & $3.4 \times 10^{-3}$ \\
N400, no DNA & NA & NA & NA & $<10^{-8}$ \\
GG1 & - & - & + & $10^{-6}-10^{-7 *}$ \\
GG2 & - & - & + & $10^{-6}-10^{-7 *}$ \\
GG5 & - & - & + & $10^{-6}-10^{-7 *}$ \\
GG11 & - & - & + & $10^{-6}-10^{-7}$ \\
GG22 & - & - & + & $10^{-6}-10^{-7 \star}$ \\
GGermC & - & - & + & $10^{-6}-10^{-7 *}$ \\
GG16 & + & + & - & $4.7 \times 10^{-3}$ \\
\hline
\end{tabular}

$(+)$, present; (-), absent; NA, not applicable.

- The transformation frequencies for these strains were $10^{-6}-10^{-7}$ and there were no statistically significant differences between them. 
A

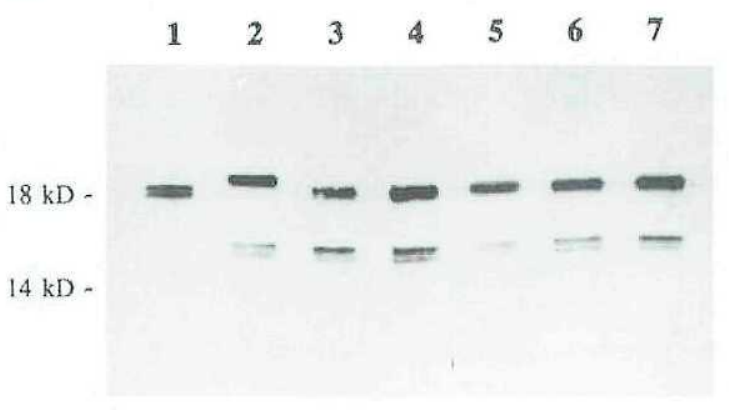

B

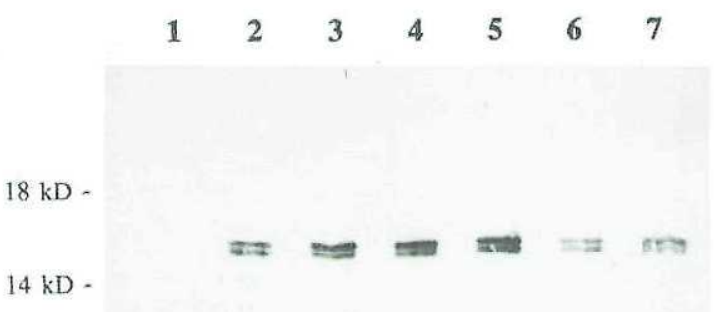

Fig. 6. Immunoblotting of whole-cell lysates (A) and concentrated culture supernatants $(B)$ of wild-type and mutant gonococcal strains. The filter was reacted with rabbit antiserum raised against gonococcal pili at a dilution of 1:2000. The positions of 14 and $18 \mathrm{kDa}$ protein molecular mass standards are shown on the left. Lanes 1, N400; 2, VD302 P gly-1 - ser-1; 3, GG5; 4, GG22; 5, GG2; 6 , GG11; 7, GGermC.

non-piliated and that these mutants failed to give rise to piliated revertants at detectable levels. Reversion might be expected to occur readily if their non-piliated status resulted from pilin variation generated by recombination at pilE.

\section{Direct assessment of pilG function in non-polar mutant strains of gonococci}

The organization of the pilG-pilD genes suggested that they may be part of an operon or that a promoter for pilD may map within pilG. This situation raised the possibility that insertions in pilG might exhibit polarity on pilD. This did not appear to be the case as pilin in the mutants appeared to be completely processed. None the less, it seemed remotely possible that a reduced level of pilD expression might account for non-piliation if the kinetics of the polymerization were disrupted. In such a scenario, the rate of cleavage might be reduced in a way that precluded assembly, although sufficient PiID was present to cleave all pilin detected as a steady-state population. Therefore, we constructed a strain in which pilD expression was placed under the control of an exogenous promoter such that potential polarity from the pilG mutations was alleviated. This was done by placing an $8 \mathrm{~kb}$ restriction fragment that contained the tet $M$ gene into a unique intergenic BstYI site (pGDtetM, Fig. 1) and then moving this construct into the genome of strain VD300 by transformation to yield strain GDtetM. This strain was piliated and expressed a colony morphology phenotype identical to its progenitor, VD300. Moreover, pilin detected in this background by immunoblotting yielded a pattern indistinguishable from that seen for $\mathrm{N} 400$ (Fig. 7, lanes 1 and 3 ) with no antigen detected corresponding to unprocessed pilin (Fig. 7, lane 6). This indicated that sufficient PilD was expressed by this strain to promote pilus assembly in an otherwise wild-type background.

The pilG transposon mutations were then moved into the genome of GDtetM by transformation. After ensuring the correct introduction of the mutations and retention of the tet $M$ construct by Southern hybridization analysis, pilus expression was assessed by TEM. With the single exception of transformants carrying mTnErm-16 (Fig. 1), all GDtetM transformants were non-piliated (data not shown). As stated previously for the Mc mutants, it is important to note that all primary $\mathrm{mTnE}$.m transformants (excluding those derived from mTnErm-16) were nonpiliated and that these mutants failed to give rise to piliated revertants at detectable levels. When pilin expression was examined by immunoblotting in the non-piliated transformants, patterns identical to those previously seen in N400-derived mutants were found (Fig. 7, lanes 2, 4, and 5); i.e. only the slower migrating species of the doublet seen in GDtetM was found along with a form corresponding to S-pilin. Given the concordance between the data obtained here and that found for N400 derivatives, it is reasonable to surmise that the loss of pilus expression in pilG mutants cannot be ascribed to polarity on pilD expression.

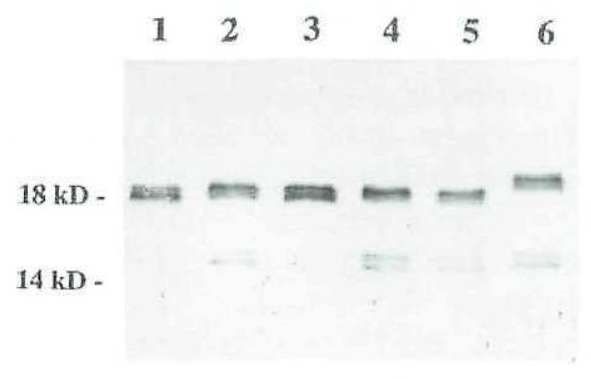

Fig. 7. Immunoblotting of whole-cell lysates of wild-type and mutant gonococcal strains. The filter was reacted with polyclonal rabbit antiserum raised against purified gonococcal pili at a dilution of $1: 2000$. The position of 14 and $18 \mathrm{kDa}$ protein size standards are shown on the left. Lanes 1, N400; 2, GG2; 3, GDtetM: 4, GDtetM with mTnErm-2 mutation; 5, GDtetM with mTnErm-1 mutation; 6 , GD 4180 (N400 carrying a deletion mutation in pilD; Freitag et al., 1995). 


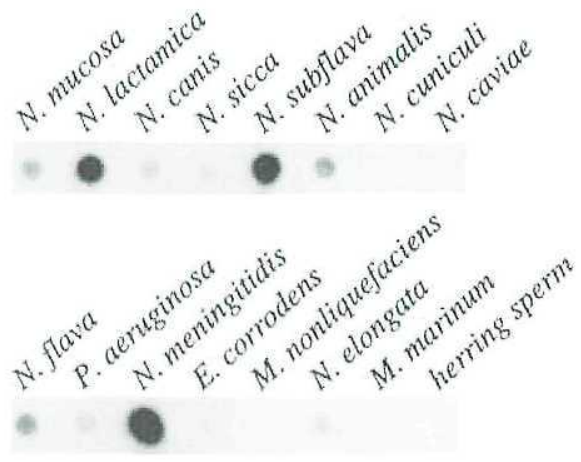

Fig. 8. Dot-blot hybridization of genomic DNAs from a variety of commensal Neisseria species using a radioactively labelled pilGspecific PCR probe. Lanes 1, Neisseria mucosa ATCC 25996; 2 , Neisseria lactamica ATCC 23970; 3. Neisseria canis ATCC 14687; 4. Neisseria sicca ATCC 29193; 5 , Neisseria subflava ATCC 10555; 6, Neisseria animalis CPH8; 7. Neisseria cuniculi ATCC 14688; 8 , Neisseria caviae ATCC 14659; 9 , Neisseria flava ATCC 14221; 10, P. aeruginosa PAK; 11, N. meningitidis 44/76-A; 12 , E. corrodens $31745 / 80 ; 13, M$. nonliquefaciens NCTC $7784 ; 14$, Neisseria elongata $6171 ; 15, M$. marinum TMC 1218; 14 , herring sperm.

Presence of pilG gene homologues in commensal neisseriae and other species

DNAs from a variety of commensal Neisseria and other species known to express type IV pili or type IV pilusassociated phenotypes were screened by dot-blot hybridization using a Mc pilG-specific polymerase chain reaction (PCR) probe (Fig. 8). The probe hybridized strongly to DNAs of most of the commensal Neisseria analysed, while a weaker hybridization signal was detected with DNAs of $P$. aeruginosa and Eikenella corrodens (a member of the family Neisseriaceae). The $P$. aeruginosa DNA signal serves as an internal standard as the precise nucleic acid homologies between the probe and the pilC and $x c p S$ genes are known to be $54 \%$ and $45 \%$, respectively (Nunn et al., 1990; Bally et al., 1991a, b). Less homology was detected with DNAs of Neisseria cuniculi, Neisseria caviae and Moraxella nonliquefaciens (members of the family Moraxellaceae). Southern blotting indicated that the hybridization signals seen are restricted to distinct DNA fragments and therefore do not represent spurious or random reactivities (data not shown). No hybridization signals were detected with control DNAs from Mycobacterium marinum and herring sperm.

\section{Discussion}

It has been demonstrated previously that $N$. gonorrhoeae possesses genes which encode proteins with substantial similarities to those in other species responsible for type IV pili assembly and a specialised pathway of protein export (Lauer et al., 1993). This work represents an extension of that study and describes the identification and characterization of the pilG genes of both $N$. gonorrhoeae and $N$. meningitidis. The Gc gene was identified by virtue of its presence upstream of pilD and the Mc gene was identified and cloned by virtue of homology to the Gc gene. We have shown that $\mathrm{Gc}_{\mathrm{c}}$ and Mc mutants bearing defined lesions in pilG are completely devoid of pili. Efforts have been made to ensure that these results cannot be explained by pilin gene alterations or polarity exerted on downstream gene (i.e. pilD) expression. As such, these studies demonstrate an essential role for PilG in Gc pilus biogenesis. Although the experiments in Mc were not subject to the same degree of rigour, analogous results in this background can be most easily explained by a similar interpretation.

Prior to this work, only two genes have been directly implicated in Gc and Mc pilus assembly: pilE, encoding the pilin subunit and pilC, encoding large $(>110 \mathrm{kDa})$ proteins which appear to be associated with the outer membrane. While an essential role for pilin in assembly is obvious, the situation for PilC is less clear. The original description of spontaneous pilC mutants in Gc reported that they were not bald but, in fact, expressed low levels of pili (Jonsson et al., 1991). Earlier studies using the very same recombination-deficient strains noted that the most frequent class of variants expressed reduced levels of pili (Koomey et al., 1991) and these have been subsequently demonstrated to be pilC mutants $(H$. Seifert, personal communication).

A consistent theme of these studies is the striking similarities between the Gc and Mc pilus-assembly components and those identified in $P$. aeruginosa (Nunn et al., 1990) and Pseudomonas putida (deGroot et al., 1994). The results with pilG are complementary to and in agreement with those found for pilC in P. aeruginosa (Koga et al., 1993). In each case, the lack of pilus expression cannot be accounted for by polarity of upstream mutations on pilD expression and thus members of this protein family play their own distinctive and essential role in pilus assembly. Although their precise role(s) remains enigmatic, their predicted or demonstrated localization in the cytoplasmic membrane and linkage of their genes to those encoding pre-pilin leader peptidases suggest that they function in the initial stages of pilus assembly.

One distinctive feature of the organization of the Gc and $\mathrm{Mc}$ pilG and pilD genes is the presence of $73 \mathrm{bp}$ intergenic regions, whereas in $P$. aeruginosa and $P$. putida, the corresponding intergenic spacings are 3 and $2 \mathrm{bp}$ in size, respectively (Nunn et al., 1990; deGroot et al., 1994). Dupuy and Pugsley (1994) noted the presence of four potential promoters for Gc pilD which, based on the data presented here, would all map within the pilG open reading frame. None of these putative promoters would be disrupted in the mutants examined here. Koga and colleagues (1993) raised the formal possibility that pilC (the homologue

\footnotetext{
C. 1995 Blackwell Science Ltd, Molecular Microbiology, 16, 451-464
} 
of $\mathrm{Gc}$ pilG) and pilD are co-transcribed from the pilC promoter in $P$. aeruginosa. Given the extremely low levels of PilD needed for pilin processing in Gc (N. Freitag and M. Koomey, unpublished), the absence of any readily identifiable promoters $3^{\prime}$ of the pilG termination codon and the presence of potential transcription attenuating/RNA processing signals $3^{\prime}$ of pilG, it is conceivable that a similar operon structure exists for the Gc and Mc pilG-pilD genes. If this is true, then pilD expression in the mTnErm mutants may be dependent on transcription initiated in the transposon. Clarification of this aspect of Gc pilG and pilD expression warrants further study. Additional mutant analysis has shown that the genes upstream of pilG are non-essential for pilus assembly and, taken together with other results (Freitag et al., 1995), it appears that the locus spanning pilF to pilG appears to define the immediate gene cluster engaged in Gc and Mc pilus biogenesis.

Altered pilin profiles in Gc pilG mutants were similar to those seen previously in non-piliated pilin gene mutants and mutants expressing reduced levels of pili. As originally proposed, the inverse correlation between these alterations and levels of piliation can most easily be ascribed to S-pilin processing being a consequence of non-assembly (Koomey et al., 1991). The findings of Spilin in pilG mutants further supports this model. Another consistent perturbation in pilin expression has been seen in pilG and pilC Gc mutants (Koomey et al., 1991; Jonsson et al., 1992). In wild-type Gc expressing the particular pilE allele found in VD300 and its derivatives, pilin was detected as a doublet with the faster migrating species co-migrating with pilin present in purified pili. However, only the slower migrating species was detected in pilG and pilC mutants (Koomey et al., 1991; Jonsson et al., 1992). That both species appear to have been processed by pre-pilin leader peptidase suggests that an additional form of post-translational pilin processing exists but its nature remains obscure. Studies in $P$. aeruginosa have shown that undermethylation of pilins occurs in mutants failing to express PilC (the homologue to GC PilG) but methylation did not alter the relative mobility of pilin in that system (Strom et al., 1993). Recent evidence suggests that the pilin subunits in meningococci may be differentially glycosylated and that glycosylation appears to influence pilin mobility in SDS-PAGE (Virji et al., 1993). Whatever the basis for the two species, the failure to find the faster migrating form in Gc pilG and pilC mutants may indicate that this as yet uncharacterized processing does not occur in these backgrounds. Alternatively, we speculate that specific degradation of the mature (faster migrating) pilin into S-pilin may account for its absence in the mutants. Efforts directed at deciphering the basis for these observations are currently underway.

Much of the interest in $G_{c}$ and Mc pili stems from their apparent significance to the pathogenesis of human infection. This correlation is most easily rationalized by the increased adherence of piliated cells for epithelial tissue as seen using in vitro models; however, not all piliated variants display this property (Rudel et al., 1992; Viri et al., 1993; Jonsson et al., 1994; Nassif et al., 1994). Autoagglutination, twitching motility, and competence for transformation are other pilus-associated phenotypes which may influence the biology of host-parasite interactions. While the strong correlation between pilus expression and competence has been demonstrated in many studies (Froholm et al.,1973; Seifert et al., 1991; Zhang et al., 1992), its molecular basis has remained elusive. Some have the opinion that pilin production alone, rather than the actual formation of pili, is the essential prerequisite for transformation competence (Gibbs et al., 1989; Meyer et al., 1990), while data from our prior studies are most consistent with competence requiring the expression of the assembled organelle (Zhang et al., 1992). The data obtained here with pilG mutants lend strong support to the latter position. Along with virtually identical results found for Gc pilF and pilD mutants (Freitag et al., 1995), these findings represent the first reports of defined, non-pilin gene mutations that directly link pilus expression and competence. These results have particular significance for studies of competence in Bacillus subtilis where an essential surface-localized structure analogous to type IV pili has been predicted based on genetic data (Dubnau, 1991; Hobbs and Mattick, 1993), but not yet demonstrated. In addition to the defects in bacterial aggregation and transformation ability manifested in pilG mutants, twitching motility and adherence to human epithelial cells are abolished or greatly diminished, respectively, in this background (S. Drake and M. Koomey, unpublished data).

A major finding stemming from these studies is that much of the basic machinery for Gc and Mc pilus assembly is highly conserved. Further evidence of this conservation can be found at the level of gene organization. Macrorestriction mapping of the Mc strain 44/76 genome using DNA probes derived from the pilF-pilG locus and other genes (pilQ (S. Drake and M. Koomey, submitted), pilT (Lauer et al., 1993) and pile (Meyer et al., 1984; Potts and Saunders, 1988)) has revealed that the genes modifying pilus expression are distributed throughout the genome (A. B. Kolstø and L. O. Froholm, personal communication). These data closely mirror that reported for the localization of these same genes in Gc strain FA 1090 (Dempsey and Cannon, 1994). In addition, pilG homologous sequences were detected in related commensal bacterial species expressing type IV pili or exhibiting phenotypes associated with type IV pilus expression. These findings were reminiscent of analogous results found using the Gc pilD gene as a probe (Dupuy and Pugsley, 
1994). Taken together, the observations imply that type IV pilus-assembly genes are conserved and widely distributed in these species as well. Given the existence of highly related genes involved solely in protein export and nucleic acid transport, the specific dedication of the putative genes to pilus assembly in these species remains to be demonstrated. These studies represent one part of our general approach to understanding the mechanisms of neisserial pilus biogenesis and the role(s) which pili play in the pathogenesis of gonococcal and meningococcal disease.

\section{Experimental procedures}

\section{Bacterial strains, media and plasmids}

All bacterial strains used are listed in Table 3. N. gonorrhoeae (Gc) and N. meningitidis (Mc) were propagated on clear solid $\mathrm{GC}$ media at $36{ }^{\circ} \mathrm{C}$ in $5 \% \mathrm{CO}_{2}$ or in liquid $\mathrm{GC}$ media that had been preincubated overnight in $5 \% \mathrm{CO}_{2} . \mathrm{N}$. meningitidis strain 44/76 was isolated from a fatal case of meningitis and septicaemia (Holten et al., 1979) and is the source for current meningococcal vaccine development in Norway. Gc and Mc transformants were selected on solid GC media containing $8 \mu \mathrm{g} \mathrm{ml}^{-1}$ erythromycin or $5 \mu \mathrm{g} \mathrm{ml}^{-1}$ rifampin (Sigma). E. coli strains HB101 and DH5 $\mathrm{F}^{\prime} \mathrm{IQ}$ were used in plasmid cloning experiments while strain KW251 was used in the propagation of recombinant phage clones. E. coli strains were grown at $37^{\circ} \mathrm{C}$ in Luria-Bertani (LB) medium supplemented with appropriate antibiotics: chloramphenicol, $10 \mu \mathrm{g} \mathrm{ml}^{-1}$ (Sigma), erythromycin, $300 \mu \mathrm{g} \mathrm{ml}^{-1}$ (Sigma) or carbenicillin, $100 \mu \mathrm{g} \mathrm{ml}^{-1}$ (Sigma) and $\mathrm{X}$-gal $\left(40 \mu \mathrm{g} \mathrm{ml}^{-1}\right)$ when appropriate. The plasmids used in this study are listed in Table 4.

\section{DNA preparation and manipulation}

Gonococcal and meningococcal genomic DNAs were prepared by standard methods (Sambrook et al., 1989). Isolation and purification of plasmid and phage DNAs were performed using Qiagen columns (Diagen, Germany) according to the manufacturer's specifications. For the phage library, meningococcal DNA partially digested with SauZAI endonuclease was fractionated by electrophoresis and fragments $15-20 \mathrm{~kb}$ in size were recovered by electroelution. This DNA was ligated into BamHI-digested EMBL-3 phage arms (Frischauf et al., 1983) and encapsidated in phage particles using a Gigapack II Plus packaging extract (Stratagene). Other standard methods of DNA manipulation were performed as described (Sambrook et al., 1989). DNA sequencing was performed by the dideoxy chain-termination method (Sanger et al., 1977) using a modified form of T7 DNA polymerase (Sequenase version 2.0, United States Biochemicals). The complete sequence of both strands was determined by subcloning, as well as by the use of appropriate deletion constructs and unique oligonucleotide primers. High stringency Southern and dot-blot hybridations were performed according to published methodologies (Tønjum et al., 1992). The pilG-specific hybridization probe covered nucleotides $272-1123$ in the sequence (accession number U19580) and was generated by a PCR protocol using standard procedures (Perkin-Elmer Cetus) and the primers $T$ T36 (5'-CTITGAAGGCAGGCATTC-3') and TT37 (5'-GCGCCGGCAGTGGAGTCC-3').

\section{General protocols}

Gonococcal and meningococcal mutants failing to express functional PilG were constructed primarily by shuttle mutagenesis using the mini-transposon mTnErm (a derivative of Tn3) as described (Seifert et al., 1991). The precise sites of the transposon insertions were determined by DNA sequencing with primer Tn3L (5'-CTCATGACCAAAATCCC- $3^{\prime}$ ) which is complementary to sequences at one end of the transposon.

Table 3. Bacterial strains used in this study.

\begin{tabular}{|c|c|c|}
\hline Species and strains & Relevant characteristics & Source/Referer \\
\hline \multicolumn{3}{|l|}{ N. gonorrhoeae } \\
\hline VD300 & $\begin{array}{l}\text { Piliated, Opa }{ }^{-} \text {, derivative } \\
\text { of MS11 }\end{array}$ & $\begin{array}{l}\text { Koomey et al. } \\
\text { (1991) }\end{array}$ \\
\hline N400 & $\begin{array}{l}\text { VD300, recA6 } \\
\text { (IPTG-inducible recA) }\end{array}$ & This work \\
\hline VD302 P Gly-1 - Ser-1 & $\begin{array}{l}\text { Mutant pilin resistant to } \\
\text { pre-pilin peptidase activity }\end{array}$ & $\begin{array}{l}\text { Koomey et al. } \\
\text { (1991) }\end{array}$ \\
\hline GGseries & $\begin{array}{l}\text { pilG::mTnErm transposon } \\
\text { insertions in } \mathrm{N} 400\end{array}$ & This work \\
\hline GDtetM & $\begin{array}{l}\text { VD300 with pilD under the } \\
\text { control of an exogenous } \\
\text { promoter }\end{array}$ & This work \\
\hline
\end{tabular}

$\underline{\text { N. meningitidis }}$ $44 / 76-\mathrm{A}$

Piliated variant of $44 / 76$ (serogroup B:15:P1.7, 16:L3,7-selected by pellicle formation)

MG-series pilG::mTnErm transposon insertions in Neisseria meningitidis 44/76-A

Commensal and other species

\begin{tabular}{|c|c|c|}
\hline N. lactamica 23970 & Type strain & ATCC \\
\hline N. subflava 10555 & Type strain & ATCC \\
\hline N. sicca 29193 & Type strain & ATCC \\
\hline N. cinerea 14685 & Type strain & ATCC \\
\hline N. mucosa 25996 & Type strain & ATCC \\
\hline N. animalis CPH 8 & Reference strain & K. Bøvre \\
\hline N. canis 14687 & Type strain & ATCC \\
\hline N. cuniculi 14688 & Type strain & ATCC \\
\hline N. caviae 14659 & Type strain & ATCC \\
\hline N. elongata 6171 & Reference strain & $\begin{array}{l}\text { Tonjum et } \\
\text { (1992) }\end{array}$ \\
\hline P. aeruginosa PAK & Reference strain & D. Bradley \\
\hline $\begin{array}{l}\text { E. corrodens } \\
31745 / 80\end{array}$ & Reference strain & $\begin{array}{l}\text { Tonjum et } \\
\text { (1993) }\end{array}$ \\
\hline $\begin{array}{l}\text { M. nonliquefaciens } \\
\text { NCTC } 7784\end{array}$ & Reference strain & $\begin{array}{l}\text { Tonjum et } \\
\text { (1992) }\end{array}$ \\
\hline M. marinum 927 & Type strain & ATCC \\
\hline E. coli HB101 & $\begin{array}{l}\mathrm{F}^{-}, \text {mcrB mrr hsdS20 } \\
\left(\mathrm{r}_{\mathrm{B}}^{-}, \mathrm{m}_{\mathrm{B}}\right) \text { recA13 supE44 } \\
\text { ara14 galk2 lacYl proA2 } \\
\text { rpsL20 xyl15 leu mt/11 }\end{array}$ & BRL \\
\hline E. coli $\mathrm{DH} 5 x \mathrm{~F}^{\prime} \mathrm{IQ}$ & $\begin{array}{l}\text { hsdR recA laZYABO } \\
\text { lacZM } 15\end{array}$ & BRL \\
\hline E. coli KW251 & 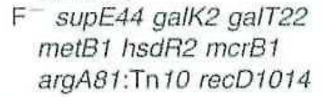 & Promega \\
\hline
\end{tabular}

Holten et al. (1979); this work

This work 
Table 4. Plasmids used in this study.

\begin{tabular}{|c|c|c|}
\hline Plasmids & Relevant characteristics & Source/Reference \\
\hline pACYC184 & Cloning vector, Tet ${ }^{R}$ & $\begin{array}{l}\text { New England } \\
\text { Biolabs }\end{array}$ \\
\hline pBluescript II SK/KS & Cloning vector, $A m p^{R}$ & Stratagene \\
\hline pHSS6 & 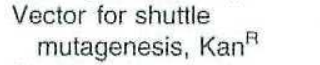 & $\begin{array}{l}\text { Seifert et al. } \\
\text { (1991) }\end{array}$ \\
\hline pOx::mTnErm & $\begin{array}{l}\text { Shuttle mutagenesis, } \\
\text { conjugative } \mathrm{F} \text { factor } \\
\text { derivative with } \mathrm{mTnE} \text { Erm }\end{array}$ & $\begin{array}{l}\text { Seifert et al. } \\
\text { (1991) }\end{array}$ \\
\hline pTCA & $\begin{array}{l}\text { Shuttle mutagenesis, } \\
\text { Tet }^{\sharp} \text {, expresses Tn3 } \\
\text { transposase } \\
\text { constitutively }\end{array}$ & $\begin{array}{l}\text { Seifert et al. } \\
\text { (1991) }\end{array}$ \\
\hline pTT1 & $\begin{array}{l}\text { Clal-Sall fragment } \\
\text { containing Gc pilG in } \\
\text { pACYC184 }\end{array}$ & This work \\
\hline$p \pi 1_{f s, x_{\text {mal }}}$ & $\begin{array}{l}\text { pTT1 with frame-shift } \\
\text { mutation in pilG at } \\
\text { Xmal site }\end{array}$ & This work \\
\hline рाT2 & $\begin{array}{l}\text { BamHI-Clal fragment } \\
\text { containing Gc pilG } \\
\text { cloned into pBSIISK }\end{array}$ & This work \\
\hline pTT2ermC & $\begin{array}{l}\text { p TT2 with erm gene } \\
\text { cassette in Smal site }\end{array}$ & This work \\
\hline рТтЗ & $\begin{array}{l}\text { Smal-Sall fragment } \\
\text { containing part of Go } \\
\text { pilG in pHSS6 }\end{array}$ & This work \\
\hline рTा4 & $\begin{array}{l}\text { Eagl-Bst YI fragment } \\
\text { containing complete Gc } \\
\text { pilG in pBSIISK }\end{array}$ & This work \\
\hline рTा5 & $\begin{array}{l}\text { Eagl-fragment containing } \\
\text { McpilG, pilD, pilF } \\
\text { genes in pBSIIKS }\end{array}$ & This work \\
\hline pGDtetM & $\begin{array}{l}\text { tet } M \text { gene containing } \\
\text { restriction fragment } \\
\text { cloned upstream of } \\
\text { pilD }\end{array}$ & This work \\
\hline
\end{tabular}

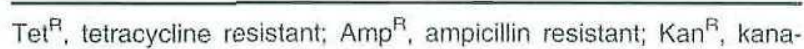
mycin resistant.

One mutation was constructed by site-specific insertion of an erythromycin-resistance gene cassette (Projan et al., 1987). These mutations were introduced into $N$. gonorrhoeae $N 400$ by genetic transformation using linearized plasmid DNAs. The N400 strain harbours the recA6 allele in which the recA gene is under the control of an inducible taclac promoter $(\mathrm{H}$. Seifert, personal communication). The recA6 construct also contains the $\mathrm{IaCl}^{a}$ repressor gene and the tetM gene as an associated selectable marker. For transformation, RecA expression and recombination functions were transiently induced in this background by IPTG addition to a final concentration of $200 \mu \mathrm{g} \mathrm{ml}^{-1}$ at the same time at which transforming DNA was added. Linearized pilG-mTnErm plasmids were also transformed into $N$. meningitidis strain 44/76-A. Introduction of specific transposon insertions into the genome of recipients was verified by Southern hybridization analysis with ermC- and pilG-specific hybridization probes labelled with ${ }^{32} \mathrm{P}$. The complete pilE nucleotide sequence of each mutant was determined by PCR-based thermocycle sequencing using Vent polymerase (New England Biolabs) and customized oligonucleotide primers.

Polypeptides encoded by plasmids were identified by means of an in vitro coupled transcription-translation system analysis of plasmid DNA. Purified plasmid DNAs were used to prime the reactions according to the supplier's recommendations (Promega) with $\left[{ }^{35} \mathrm{~S}\right]-$ methionine (Amersham). Labelled polypeptides were separated by SDS-PAGE, transferred to nitrocellulose filters by electroblotting and visualized by autoradiography.

Competence for natural transformation of $\mathrm{Gc}$ and $\mathrm{MC}$ strains was assessed as detailed (Zhang et al., 1992) using chromosomal DNA from a spontaneous rifampin-resistant mutant of VD300.

Detection of pilin antigen in whole-cell lysates and concentrated culture supernatants were performed using rabbit polyclonal pilin-specific antibodies raised against $N$. gonorrhoeae pili (lot 2-66) and $P$. aeruginosa PAK pili (lot 526). Conditions for sample preparation, SDS-PAGE, electroblotting and antigen detection have been described previously (Koomey et al., 1991).

DNA and peptide sequence data were compiled and analysed by computer using the MacVector version 3.5 and University of Wisconsin Genetics Computer Group (UWGCG) software packages (Devereux et al., 1984). DNA homologies were found using the FASTA routine and protein homologies were identified using IFASTA. Pairwise alignments of proteins were performed using the GAP and BESTFIT programs with default parameters.

\section{Transmission electron microscopy}

Prior to examination in the electron microscope, strains were grown on GC agar for $14-17 \mathrm{~h}$ and harvested in $1 \%$ ammonium acetate, $\mathrm{pH} 7.2$. Droplets $(5 \mu \mathrm{l})$ of the solutions were placed on carbon filmed grids and left for $1 \mathrm{~min}$, blotted almost dry and negatively stained for anothermin with $0.25 \%(\mathrm{Gc})$ and $0.50 \%(\mathrm{Mc})$ sodium phosphotungstic acid (NaPT), pH7.0. The grids had previously been glow discharged in air to facilitate spreading of both the bacteria and the stain. The specimens were examined in a Jeol 1010 microscope operated at $100 \mathrm{KeV}$.

\section{Uncoupling pilD expression from pilG by use of an exogenous promoter}

Plasmid pGD carries the Gc pilD gene and flanking sequences on a $2.6 \mathrm{~kb}$ Smal-Hpal fragment (N. Freitag, and $M$. Koomey, submitted). An $8 \mathrm{~kb}$ Notl-fragment from pHSX-tetMlaclP (H.S. Seifert, personal communication) containing the tet $M$ gene was isolated and inserted immediately upstream of pilD at the Bst YI site in PGD in the orientation shown in Fig. 1 to create pGDtetM. This construct placed the pilD gene under the control of an exogenous promoter present in the inserted restriction fragment, presumably the tet $M$ promoter. This construct was introduced into N. gonorrhoeae VD300 by transformation and selection for tetracycline resistance to produce strain GDtetM. The $\mathrm{mTnErm}$ mutations were then transformed into GDtetM.

\section{Acknowledgements}

We thank R. Fox for technical assistance and $H$. Seifert for generously sharing the recA6 allele and $\mathrm{pHSX}$-tetMlaclP 
constructs prior to publication. We also thank A. B. Kolstø and L. O. Frøholm for providing the meningococcal pulsed-field gel mapping data. We are grateful to K. Bovre for his support of these studies. This work was supported by Public Health Service Grant Al27837 and NIH Grant M01 RR 00042. T.T. was a recipient of grant support from the Anders Jahre and the Fulbright Foundations. M.K. is a PEW scholar in the Biomedical Sciences.

\section{References}

Aho, E.L., and Cannon, J.G. (1988) Characterization of a silent pilin gene locus from Neisseria meningitidis strain FAM18. Microb Pathogenesis 5: 391-398.

Albano, M., Breitling, R., and Dubnau, D.A. (1989) Nucleotide sequence and genetic organization of the Bacillus subtilis comG operon. J Bacteriol 171: 5386-5404.

Bally, M., Ball, G., Badere, A., and Lazdunski, A. (1991a) Protein secretion in Pseudomonas aeruginosa. The xсpA gene encodes an integral inner membrane protein homologous to Klebsiella pneumoniae secretion function protein PulO. J Bacteriol 173: 479-486.

Bally, M., Filloux, A., Akrim, M., Ball, G., Lazdunski, A., and Tommassen, J. (1991b) Protein secretion in Pseudomonas aeruginosa: characterization of seven $x c p$ genes and processing of secretory apparatus components by prepilin peptidase. Mol Microbiol 6: 1121-1131.

Blake, M.S., MacDonald, C., and Klugmann, K.P. (1989) Colony morphology of piliated Neisseria meningitidis. J Exp Med 170: 1727-1736.

Dempsey, J.E., and Cannon, J.G. (1994) Locations of genetic markers on the physical map of the chromosome of Neisseria gonorrhoeae FA1090. I Bacteriol 176: 20552060.

Devereux, J., Haeberli, P., and Smithies, O. (1984) A comprehensive set of sequence analysis programs for the VAX. Nucl Acids Res 12: 387-395.

Dubnau, D. (1991) Genetic competence in Bacillus subtilis. Microbiol Rev 55: 395-424.

Dums, F., Dow, J.M., and Daniels, M.J. (1991) Structural characterization of protein secretion genes of the bacterial phytopathogen Xanthomonas campestris pathovar campestris: relatedness to secretion systems of other Gramnegative bacteria. Mol Gen Genet 229: 357-364.

Dupuy, B., and Pugsley, A.P. (1994) Type IV pre-pilin peptidase gene of Neisseria gonorrhoeae MS11: presence of a related gene in other piliated and non-piliated Neisseria strains. J Bacteriol 176: 1323-1331.

Freitag, N., Seifert, H.S., and Koomey, M. (1995) Characterization of the pilf-pilD pilus assembly locus of Nesseria gonorrhoeae. Mol Microbiol, in press.

Frischauf, A.M., Lehrach, H., Poustka, A., and Murray, N. (1983) Lambda replacement vectors carrying polylinker sequences. J Mol Biol 170: 827-842.

Frøholm, L.O., Jyssum, K., and Bøvre, K. (1973) Electron microscopical and cultural features of Neisseria meningitidis competence variants. Acta Path Microbiol Scand 81: 525-537.

Gibbs, C.P., Reimann B.Y., Schultz, E., Kaufmann, A., Haas, R., and Meyer, T.F. (1989) Reassortment of pilin genes in
Neisseria gonorrhoeae occurs by two distinct mechanisms. Nature 338: 651-652.

Giron, J.A., Ho., A.S.Y., and Schoolnik, G.K. (1991) An inducible bundle-forming pilus of enteropathogenic Escherichia coli. Science 254: 710-714.

de Groot, A., Heijnen, I., deCock, H., Filloux, A., and Tommassen, J. (1994) Characterization of Type IV pilus genes in plant growth-promoting Pseudomonas putida WCS358. J Bacteriol 176: 642-650.

Haas, R., and Meyer, T.E. (1986) The repertoire of silent pilus genes in Neisseria gonorrhoeae: evidence for gene conversion. Cell 44: 107-115.

Haas, R., Schwarz, H., and Meyer, T.E. (1987) Release of soluble pilin antigen coupled with gene conversion in Neisseria gonorrhoeae. Proc Natl Acad Sci USA 84: 9079 9083.

He, S.Y., Lindeberg, M., Chatterjee, A.K., and Collmer, A. (1991) Cloned Erwinia chrysanthemi out genes enable Escherichia coli to selectively secrete a diverse family of heterologous proteins into its milieu. Proc Natl Acad Sci USA 88: 1079-1083.

Heckels, J.E. (1989) Structure and function of pili of pathogenic Neisseria species. Clin Microbiol Rev 2: S66S73.

Hobbs, M., and Mattick, J.S. (1993) Common components in the assembly of type IV fimbriae, DNA transfer systems, the filamentous phage and protein-secretion apparatus: a general system for the formation of surface-associated protein complexes. Mol Microbiol 10: 233-243.

Holten, E. (1979) Serotypes of Neisseria meningitidis isolated from patients in Norway during the first six months of 1978 . $J$ Clin Microbiol 9: 186-187.

Hultgren, S., and Normark, S. (1991) Biogenesis of the bacterial pilus. Curr Opin Gen Develop 1: 313-318.

Jaeger, J.A., Turner, D.H., and Zuker, M. (1989) Predicting optimal and suboptimal secondary structure of RNA. Meth Enzymol 183: 281-306.

Jiang, B., and Howard, S.P. (1992) The Aeromonas hydrophila exeE gene, required both for protein secretion and normal outer membrane biogenesis, is a member of a general secretion pathway. Mol Microbiol 6: 1351-1361.

Jonsson, A.B., Nyberg. G., and Normark, S. (1991) Phase variation of gonococcal pili by a frameshift mutation in pilC, a novel gene for pilus-assembly. EMBO J 10: 477-488.

Jonsson, A.B., Pfeiffer, J., and Normark, S. (1992) Neisseria gonorrhoeae PilC expression provides a selective mechanism for structural diversity of pili. Proc Natl Acad Sci USA 89: 3204-3208.

Jonsson, A.B., Ilver, D., Falk, P., Pepose, J., and Normark, S. (1994) Sequence changes in the pilus subunit lead to tropism variation of Neisseria gonorrhoeae to human tissue. Mol Microbiol 13: 403-416.

Jyssum, K., and Lie, S. (1965) Genetic factors determining competence in transformation of Neisseria meningitidis. Acta Path Microbiol Scand 63: 306-316.

Kaufmann, M.R., Shaw, C.E., Jones, I.D., and Taylor, R.K. (1993) Biogenesis and regulation of the Vibrio cholerae toxin-coregulated pilus: analogies to other virulence factor secretory systems. Gene 126: 43-49.

Kellogg, D.S., Cohen, I.R., Norins, L.C., Schroeter, A.L., and Reising, G. (1968) Neisseria gonorrhoeae II. Colonial 
variation and pathogenicity during 35 months in vitro. $J$ Bacteriol 96: 596-605.

Koga, T., Ishimoto, K., and Lory, S. (1993) Genetic and functional characterization of the gene cluster specifying expression of Pseudomonas aeruginosa pili. Infect Immun 61: $1371-1377$.

Koomey, J.M., Gotschlich, E.C., Robbins, K., Bergstrom, S., and Swanson, J. (1987) Effects of recA mutations on pilus antigenic variation and phase transitions in Neisseria gonorrhoeae. Genetics 117: 391-398.

Koomey, J.M., Bergstrøm, S., Blake, M., and Swanson, J. (1991) Pilin expression and processing in pilus mutants of Neisseria gonorrhoeae: critical role of Gly-1 in assembly. Mol Microbiol 5: 279-287.

Lauer, P., Albertson, N.H., and Koomey, M. (1993) Conservation of genes encoding components of a type IV pilusassembly/two-step protein export pathway in Neisseria gonorrhoeae. Mol Microbiol 8: 357-368.

Meyer, T.F., Billyard, E., Haas, R, Storzbach, S., and So, M. (1984) Pilus genes of Neisseria gonorrhoeae chromosomal organization and DNA sequence. Proc Natl Acad Sci USA 81: $6110-6114$.

Meyer, T.F., Gibbs, C., and Haas, R. (1990) Variation and control of protein expression in Neisseria. Annu Rev Microbiol 44: 451-477.

Nassif, X., Beretti, J.-L., Lowy, J., Stenberg, P., O'Gaora, P., Pfeifer, J., Normark, S., and So, M. (1994) Roles of pilin and PilC in adhesion of Neisseria meningitidis to human epithelial and endothelial cells. Proc Natl Acad Sci USA 91: 3769-3773.

Nunn, D.N, Bergman, S., and Lory, S. (1990) Products of three accessory genes, pilB, pilC, and pilD, are required for biogenesis of Pseudomonas aeruginosa pili. J Bacteriol 172: $2911-2919$.

Pasloske, B.L., Finlay, B.B., and Paranchych, W. (1985) Cloning and sequencing of the Pseudomonas aeruginosa PAK pilin gene. FEBS Lett 183: 408-412.

Perry, A.C.F., Nicholson, I.J., and Saunders, J.R. (1988) Neisseria meningitidis strain $\mathrm{C} 114$ contains silent truncated pilin genes that are homologous to Neisseria gonorrhoeae pil sequences. J Bacteriol 170: 1691-1697.

Potts, W.J., and Saunders, J.R. (1988) Nucleotide sequence of the structural gene for class I pilin from Neisseria meningitidis: homologies with the pilE locus of Neisseria gonorrhoeae. Mol Microbiol 2: 647-653.

Projan, S.J., Monod, M., Narayanan, C.S., and Dubnau, D. (1987) Replication properties of plM13, a naturally occurring plasmid found in Bacillus subtilis, and of its close relative pE5, a plasmid native to Staphylococcus aureus. J Bacteriol 169: 5131-5139.

Pugsley, A.P. (1993) The complete general secretory pathway in Gram-negative bacteria. Microbiol Rev 57: 50-108.

Pugsley, A.P., and Reyss, I. (1990) Five genes at the 3 ' end of the Klebsiella pneumoniae pulC operon are required for pullulanase secretion. Mol Microbiol 4: 365-379.

Rao, M.J.L., and Argos, P. (1986) A conformational preference parameter to predict helices in integral membrane proteins. Biochim Biophys Acta 869: 197-214.

Rudel, T., van Putten, J.P.M., Gibbs, C.P., Haas, R., and Meyer, T.F. (1992) Interaction of two variable proteins (PilE and PilC) required for pilus-mediated adherence of
Neisseria gonorrhoeae to human epithelial cells. Mol Microbiol 6: 3439-3450.

Sambrook, J., Fritsch, E.F., and Maniatis. T. (1989) Molecular Cloning: A Laboratory Manual, 2nd edn. Cold Spring Harbor, New York: Cold Spring Harbor Laboratory Press.

Sandkvist, M., Morales, V., and Bagdasarian, M. (1993) A soluble protein required for secretion of cholera toxin through the outer membrane of Vibrio cholerae. Gene 123: $81-86$.

Sanger, F., Nicklen, S., and Coulson, A.R. (1977) DNA sequencing with chain terminating inhibitors. Proc Natl Acad Sci USA 74: 5463-5467.

Seifert, H.S., Ajioka, R.S., Parachuri, D., Heffron, F., and So, M. (1991) Shuttle mutagenesis of Neisseria gonorrhoeae: pilin null mutations lower DNA transformation competence. $J$ Bacteriol 172: 40-46.

Shaw, C.E., and Taylor, R.K. (1990) Vibrio cholerae 0395 tcpA pilin gene sequence and comparison of predicted protein structural features to those of type 4 pilins. Infect Immun 58: 3042-3049.

Stephens, D.S., and McGee, Z.A. (1981) Attachment of Neisseria meningitidis to human mucosal surfaces: influence of pili and type of receptor cell. J Inf Dis 143: $525-532$.

Strom, M.S., Nunn, D.N., and Lory, S. (1991) Multiple roles of the pilus biogenesis protein PilD: involvement of PilD in excretion of enzymes from Pseudomonas aeruginosa. $J$ Bacteriol 173: 1175-1180.

Strom, M.S., Nunn, D.N., and Lory, S. (1993) A single bifunctional enzyme, PilD, catalyzes cleavage and $\mathrm{N}$ methylation of proteins belonging to the type IV pilin family. Proc Natl Acad Sci USA 90: 2404-2408.

Swanson, J. (1973) Studies on gonococcus infection IV. Pili: their role in attachment of gonococci to tissue culture cells. $J$ Exp Med 137: 571-589.

Swanson, J. (1978) Studies on gonococcus infection XII. Colony color and opacity variants of gonococci. Infect Immun 19: 320-331.

Swanson, J., Bergstrom, S., Robbins, K., Barrera, O., Corwin, D., and Koomey, M. (1986) Gene conversion involving the pilin structural gene correlates with pilus $+\leftrightarrow$ pilus- changes in Neisseria gonorrhoeae. Cell 47: 267-276.

Swanson, J., Kraus, S.J., and Gotschlich, E.C. (1971) Studies on gonococcus infection. I. Pili and zones of adhesion: their relation to gonococcal growth patterns. J Exp Med 134: 886-906.

Swanson, J., Robbins, K., Barrera, O., Corwin, D., Boslego, J., Ciak, J., Blake, M., and Koomey, M. (1987) Gonococcal pilin variants in experimental gonorrhoea. J Exp Med 165: $1344-1357$.

Tinsley, C.R., and Heckels, J.E. (1986) Variation in the expression of pili and outer membrane protein by Neisseria meningitidis during the course of meningococcal infection. $J$ Gen Microbiol 132: 106-113.

Tonjum, T., Caugant, D.A., and Bøvre, K. (1992) Differentiation of Moraxella nonliquefaciens, $M$. lacunata, and $M$. bovis by using multilocus enzyme electrophoresis and hybridization with pilin-specific DNA probes. I Clin Microbiol 30: 3099-3107.

Tonjum, T., Weir, S., Bøvre, K., Progulske-Fox, A., and Marrs, C.F. (1993) Sequence divergence in two tandemly 
located pilin genes of Eikenella corrodens. Infect Immun 61: $1909-1916$.

Virji, M., Saunders, J.R., Sims, G., Makepeace, K., Maskell, D., and Ferguson, D.J.P. (1993) Pilus-facilitated adherence of Neisseria meningitidis to human epithelial and endothelial cells: modulation of adherence phenotype occurs concurrently with changes in primary amino acid sequence and glycosylation. Mol Microbiol 10: 1013-1028.

Weiss, A.A., Johnson, F.D., and Burns, D.L. (1993) Molecular characterization of an operon required for pertudssis toxin secretion. Proc Natl Acad Sci USA 90: 2970-2974.
Whitchurch, C.B., Hobbs, M., Livingston, S.P., Krishnapillai, V., and Mattick, J.S. (1991) Characterization of a Pseudomonas aeruginosa twitching motility gene and evidence for a specialized protein export system widespread in eubacteria. Gene 101: 33-44.

Zhang, Q.Y., DeRyckere, D., Lauer, P., and Komey, M. (1992) Gene conversion in Neisseria gonorthoeae: evidence for its role in pilus antigenic variation. Proc Natl Acad Sci USA 89: 5366-5370. 
Copyright of Molecular Microbiology is the property of Blackwell Publishing Limited and its content may not be copied or emailed to multiple sites or posted to a listserv without the copyright holder's express written permission. However, users may print, download, or email articles for individual use. 